\title{
The utilization of protein and mineral components of diets containing white lupin or casein supplemented with lupin hulls, manganese and sodium phytate
}

\author{
J. Juśkiewicz and Z. Zduńczyk \\ Institute of Animal Reproduction and Food Research, \\ Polish Academy of Sciences \\ Tuwima 10,10-718 Olsztyn, Poland
}

(Received 10 March 1997; accepted 19 August 1997)

\begin{abstract}
A high manganese content in a casein diet, similar to that in a lupin-containing diet (about $0.3 \mathrm{~g} / \mathrm{kg}$ ), had no adverse effects on the utilization of dietary protein and retention of $\mathrm{Mn}, \mathrm{Mg}, \mathrm{Fe}$ and $\mathrm{P}$ in rat body. The addition of $10 \%$ lupin hulls caused a significant decrease in the digestibility $(89.5$ vs. $92.8 \%)$ and protein efficiency ratio ( 2.8 vs. 3.03$)$, and lowered the retention of mineral components in comparison with the control diet. Manganese retention declined from 3.84 to $1.22 \%$ of intake, phosphorus from 30.9 to $24.9 \%$, magnesium from 24 to $12.8 \%$, and iron from 26.6 to $22.1 \%$. The addition of sodium phytate to the casein diet containing lupin hulls decreased only the bioavailability of manganese (from 1.22 to $0.64 \%$ ) and phosphorus (from 24.9 to $23.0 \%$ ). The utilization of $\mathrm{P}, \mathrm{Mg}$ and $\mathrm{Fe}$ was the lowest in animals fed the diet containing white lupin seeds.
\end{abstract}

KEY WORDS: lupin, manganese, fibre, sodium phytate, protein digestibility, PER, minerals, rats

\section{INTRODUCTION}

Other wise as other legumes, white lupin is capable of storing manganese in seeds. Hung et al. (1987) found that the concentration of manganese in seeds of white lupin was twenty times higher than in a narrow-leafed variety cultivated in

* The research was financed by grant No 5 S305 03507 from the Committee for Scientific Research 
the same soil conditions. The high manganese content together with the seeds phytate and fibre, may decrease the feed value of white lupin (Cheeke and Kelly, 1989; Lantzsch,1990). The excess of manganese in the diet decreases the absorption of iron from the digestive tract and the blood haemoglobin level (Hurley and Keen,1987). Manganese may compete with iron and magnesium, reducing the activity of many enzymes in metabolic pathways (Miller, 1991). Such disorders were found at high manganese concentrations, exceeding $1 \mathrm{~g} / \mathrm{kg}$ of pig diets (Batterham, 1979), but information on the metabolic consequences of lower levels of this element (4-6 times in excess of the nutritional requirements of animals), and on the concomitant presence of other factors reducing utilization of dietary minerals, e.g. fibre and phytates, is scarce.

The purpose of this study was to investigate the effect of high dietary levels of manganese, fibre and phytates, characteristic of white lupin seeds, on the consumption and utilization of diets and on retention of $\mathrm{Mn}, \mathrm{Mg}, \mathrm{Fe}$ and $\mathrm{P}$ by rats.

\section{MATERIAL AND METHODS}

The experiments were carried out on 40 Wistar rats with initial body weight $55.2 \pm 3.8 \mathrm{~g}$. The experimental groups comprised 8 males housed individually in cages of synthetic glass, at $21-22^{\circ} \mathrm{C}$, relative humidity of $50-70 \%$ and equal periods of dark and light.

The composition of diet is given in Table 1. The control diet did not contain fibre, and the Mn content was in agreement with the nutritional requirements of rats. The source of $\mathrm{Mn}$ was manganous carbonate that is one of the components of a standard feed mixture (NRC, 1976). The experimental groups were fed diets containing one, two or three of the additional components, i.e. manganese raised to about $0.3 \mathrm{~g} / \mathrm{kg}$ (CMn diet), manganese and $10 \%$ lupin hulls (CMnF diet), or additional manganese, seed hulls and sodium phytate ( $\mathrm{CMnFPh}$ diet).

The amount of manganese, fibre and phytate was increased to the levels corresponding to their content in a diet containing about $30 \%$ white lupin seeds. In diet $\mathrm{L}$, the only source of protein were the seeds of the low-alkaloid variety of white lupin, Bardo. The Mn content in this diet $(0.38 \mathrm{~g} / \mathrm{kg})$ was slightly higher than in $\mathrm{CMn}$ diet $(0.3 \mathrm{~g} / \mathrm{kg})$. Due to the high $\mathrm{Mg}$ content in the lupin seeds, the magnesium content in $\mathrm{L}$ diet was twice the nutritional requirement of rats.

Protein efficiency ratio (PER) was determined during the 4 weeks of the experiment. True digestibility of protein (TD) was determined during a 5-day faeces collection in the last week of the experiment, the metabolic nitrogen was taken according to Rakowska et al. (1978), i.e. $46.54 \mathrm{mg} / \mathrm{rat} / 5$ days. After the growth experiment, the $\mathrm{Mn}, \mathrm{Mg}, \mathrm{Fe}$ and $\mathrm{P}$ contents were determined in homogenates of rat carcasses. The retention of elements was determined 
TABLE 1

Composition of dicts containing casein or lupin seeds, $\mathrm{g} / \mathrm{kg}$

\begin{tabular}{lccccc}
\hline & \multicolumn{5}{c}{ Group } \\
\cline { 2 - 6 } Components & $\mathrm{C}$ & CMn & CMnF & CMnFPh & L \\
\hline Casein & 119.5 & 119.5 & 112.5 & 112.5 & - \\
Lupin seeds & - & - & - & - & 300 \\
Lupin hulls & - & - & 100 & 100 & - \\
Potato starch & 100 & 100 & - & - & - \\
Mineral mixture & 30 & 30 & 30 & 30 & 30 \\
Vitamin mixture $^{2}$ & 10 & 10 & 10 & 10 & 10 \\
Soya oil & 80 & 80 & 80 & 80 & 50 \\
L-Lysine & - & - & - & - & 0.9 \\
DL-Mcthionine & 1.5 & 1.5 & 1.5 & 1.5 & 1.0 \\
MnCO & - & 0.56 & 0.51 & 0.51 & - \\
Phytate Na & - & - & - & 2.26 & - \\
Maize starch & 659.0 & 658.44 & 665.49 & 663.23 & 608.1 \\
\hline
\end{tabular}

' mineral mixture (NRC, 1976) containing in $100 \mathrm{~g}: 73.5 \mathrm{~g} \mathrm{CaHPO}_{4} ; 8.10 \mathrm{~g} \mathrm{~K}_{2} \mathrm{HPO}_{4} ; 6.80 \mathrm{~g} \mathrm{~K}_{2} \mathrm{SO}_{4}$; $3.06 \mathrm{~g} \mathrm{NaCl}_{2} 2.10 \mathrm{~g} \mathrm{CaCO}_{3} ; 2.14 \mathrm{~g} \mathrm{Na}_{2} \mathrm{HPO}_{4} ; 2.50 \mathrm{~g} \mathrm{MgO}^{2} 558 \mathrm{mg}$ ferric citrate; $81 \mathrm{mg} \mathrm{ZnCO}$; $421 \mathrm{mg} \mathrm{MnCO}_{3} ; 33.3 \mathrm{mg} \mathrm{CuCO}_{3} ; 0.7 \mathrm{mg} \mathrm{KJ}$ and $705 \mathrm{mg}$ citrate acid

${ }^{2}$ vitamin mixture (AOAC, 1975) containing in $1 \mathrm{~g}: 2000 \mathrm{IU}$ vitamin $\Lambda ; 200 \mathrm{IU}$ vitamin $\mathrm{D}_{3}$; $10 \mathrm{IU}$ vitamin $\mathrm{E} ; 0.5 \mathrm{mg}$ vitamin $\mathrm{K} ; 200 \mathrm{mg}$ choline; $10 \mathrm{mg}$ p-aminobenzoic acid; $10 \mathrm{mg}$ inositol; $4 \mathrm{mg}$ niacin; $4 \mathrm{mg}$ calcium pantothenate; $0.8 \mathrm{mg}$ riboflavin; $0.5 \mathrm{mg}$ thiamin; $0.5 \mathrm{mg}$ pyridoxine; $0.2 \mathrm{mg}$ folic acid; $0.04 \mathrm{mg}$ biotin; $0.003 \mathrm{mg}$ cobalamine; sucrose (supplement to $1 \mathrm{~g}$ )

according to the method of Davies and Nightingale (1975), i.e. from the difference between content in rat carcasses at the end of the experiment and in the "zero" group comprising 8 rats with an average body weight of $55.2 \mathrm{~g}$. The amount of $P$, $\mathrm{Mg}, \mathrm{Fe}$ and $\mathrm{Mn}$ deposited in the rat carcasses during 4 weeks of the experiment was expressed in absolute terms as daily retention, and in relation to intake.

The mineral content of the diets and rat carcasses was determined by the AAS method using a Pye Unicam Solar 939 spectrophotometer. Before assay, the samples were ashed at $450^{\circ} \mathrm{C}$.

The results of the experiments were subjected to statistical analysis in which the significance of differences was determined by the Duncan test.

\section{RLSULTS AND DISCUSSION}

Feed intake and nutritional value of diets

Feed intake, body weight gain, protein digestibility and PER values are presented in Table 2 . Increasing the manganese content of the diets did not reduce feed intake. This is in agreement with the results of Zdunczyk et al. (1996c) 
TABLE 2 Influence of manganese level, dietary fibre and Na phytatc on growth performance and protcin utilization

\begin{tabular}{lccccc}
\hline & \multicolumn{5}{c}{ Group } \\
\cline { 2 - 6 } Components & $\mathrm{C}$ & $\mathrm{CMn}$ & $\mathrm{CMnF}$ & $\mathrm{CMnFPh}$ & $\mathrm{L}$ \\
\hline Diet intake, g/28 days & $316.4^{\mathrm{b}}$ & $335.2^{\mathrm{ab}}$ & $360.5^{\mathrm{a}}$ & $354.2^{\mathrm{a}}$ & $331.6^{\mathrm{ab}}$ \\
Body weight gain, g/28 days & $102.9^{\mathrm{A}}$ & $113.9^{\mathrm{A}}$ & $112.6^{\mathrm{A}}$ & $110.4^{\mathrm{A}}$ & $76.2^{\mathrm{B}}$ \\
TD & $92.8^{\mathrm{A}}$ & $91.8^{\mathrm{AB}}$ & $89.5^{\mathrm{C}}$ & $90.5^{\mathrm{BC}}$ & $85.9^{\mathrm{D}}$ \\
PER & $3.03^{\mathrm{A}}$ & $3.05^{\mathrm{A}}$ & $2.80^{\mathrm{B}}$ & $2.78^{\mathrm{B}}$ & $2.02^{\mathrm{C}}$ \\
\hline
\end{tabular}

$\mathrm{a}, \mathrm{b}-\mathrm{P}<0.05$

A, B, C, D $-\mathrm{P}<0.01$

who found that the intake of diets containing white lupin seeds decreased only when the Mn content in the diet was $1000 \mathrm{mg} / \mathrm{kg}$. The study by Przybill and Pallauf (1991) showed that a Mn deficiency $(0.5 \mathrm{mg} / \mathrm{kg})$ of the diet had not negative effect on feed intake by rats. The addition of lupin hulls, the equivalent of about $7.6 \% \mathrm{NDF}$ and $8.1 \% \mathrm{DF}$, increased consumption of diets $\mathrm{CMnF}$ and $\mathrm{CMnFPh}$ in comparison with the control diet. The results of other authors also indicate that with an increased fibre content and lower dietary energy concentration, feed consumption usually rises (Lopez-Guisa et al., 1988; Smulikowska and Chibowska, 1993; Zduniczyk et al., 1994). The decrease in intake of the lupin containing dict (5.1 and $11 \%$ of NDF and DF, respectively) was insignificant.

Truc digestibility of protein in the control casein diet was $92.8 \%$. Increasing the $\mathrm{Mn}$ content from 0.06 to about $0.3 \mathrm{~g} / \mathrm{kg}$ did not affect negatively TD. Similar protein digestibility coefficients for the cascin dict were found by Eggum (1973). The addition of lupin hulls to the casein diet (group $\mathrm{CMnF}$ ) caused a significant decline in protein digestibility to $89.5 \%$. The negative effect of fibre on protein digestibility of diets was also found by other authors (e.g. Eggum et al., 1984; Zhao et al., 1995). The addition of $2.3 \mathrm{~g} / \mathrm{kg}$ of sodium phytate to the casein diet (group $\mathrm{CMnFPh}$ ) did not affect TD. True digestibility of white lupin seeds protein $(85.9 \%)$ was similar to that reported by Eggum et al. (1993) and Zduńczyk et al. $(1996 \mathrm{a}, \mathrm{b})$ and was significantly lower than the TD of protein in the casein groups. Also, the weight gains of the rats in group $\mathrm{L}$ (about $76.2 \mathrm{~g}$ ) were the lowest, and significantly lower than in the casein groups $(P<0.01)$.

The additional amount of manganese in the diet of group $\mathrm{CMn}$ did not lower the protein efficiency ratio. PER values in groups $C$ and $C M n$ were 3.03 and 3.05, respectively. Zduńczyk et al. (1996c) also did not find any changes in PER when the Mn content was increased from about 0.3 to $0.45 \mathrm{~g} / \mathrm{kg}$ in diets containing white lupin seeds. The addition of lupin seed hulls to the casein diet caused a significant $(\mathbf{P}<0.01)$ decrease in PER in groups $\mathrm{CMnF}$ and $\mathrm{CMnFPh}$ (by 2.80 and 2.78, respectivcly). Zduńczyk et al. (1996a) observed a similar tendency when 
they included whole and dehulled white lupin seeds in rat diets. No effect of adding sodium phytate on PER of the $\mathrm{CMnFPh}$ dict was found. The PER value was the lowest in the group receiving lupin, and was significantly lower than in the other groups. Similar PER values of seeds of Polish white lupin varieties were found by Zduńczyk et al. (1996b).

\section{Retention of trace elements}

The intake and retention of $\mathrm{Mn}, \mathrm{Mg}, \mathrm{Fe}$ and $\mathrm{P}$ are presented in Tables 3 to 6 . Increasing the Mn dietary content from 0.06 to over $0.3 \mathrm{~g} / \mathrm{kg}$ caused a significant rise in the intake of this element and a fourfold increase in the retention of manganese in the rat body (from about 33 to over $135 \mu \mathrm{g} / \mathrm{day}$ ). At the same time, the utilization of manganese declined from 4.93 to $3.84 \%$ (Table 3). Reduced utilization of Mn occurs when the concentration of this element in the diet is high (Weigland et al., 1986). These authors found that along with the increase in the Mn concentration in the rat diets to over $0.2 \mathrm{~g} / \mathrm{kg}$, true absorption declined from about 30 to about $5 \%$ of $\mathrm{Mn}$ intake. The addition of white lupin hulls decreased the retention of manganese to levels equal to those in control group. The utilization of manganese from $\mathrm{CMnF}$ diets decreased to $1.22 \%$. The addition of sodium phytate to $\mathrm{CMnF}$ diet decreased $\mathrm{Mn}$ retention from 44 to about $24 \mu \mathrm{g} / \mathrm{day}$ (nonsignificant difference), the utilization of this element was only $0.64 \%$. In the experiment by Lantzsch (1990) a very strong negative effect $(\mathrm{P}<0.001)$ of the addition of sodium phytate on the absorption of manganese in young rats was found. Davies and Nightingale (1975) also reported that phytates reduced manganese utilization. The utilization of manganese from diet $\mathbf{L}$, containing with white lupin seeds, did not differ significantly from the utilization in groups $\mathrm{CMnF}$ or $\mathrm{CMnFPh}$. This shows that the utilization of manganese from organic source (lupin) was similar to the utilization of manganous carbonate used in the cascin dicts.

TABLE 3

Influence of manganese level, dietary fibre and $\mathrm{Na}$ phytate on Mn utilization

\begin{tabular}{lccccc}
\hline & \multicolumn{5}{c}{ Group } \\
\cline { 2 - 6 } Components & $\mathrm{C}$ & $\mathrm{CMn}$ & $\mathrm{CMnF}$ & $\mathrm{CMnFPh}$ & \multicolumn{1}{c}{$\mathrm{L}$} \\
\hline Content in diet, $\mathrm{mg} / \mathrm{kg}$ & 59.6 & 287.5 & 275.9 & 306.4 & 382.5 \\
Daily intakc, mg & $0.67^{\mathrm{C}}$ & $3.51^{\mathrm{B}}$ & $3.55^{\mathrm{B}}$ & $3.87^{\mathrm{B}}$ & $4.53^{\mathrm{A}}$ \\
Content in body, mg/rat & $1.16^{\mathrm{B}}$ & $3.99^{\mathrm{A}}$ & $1.42^{\mathrm{B}}$ & $1.02^{\mathrm{B}}$ & $1.56^{\mathrm{B}}$ \\
Retention, $\mu \mathrm{g} /$ day & $33.27^{\mathrm{B} x \mathrm{c}}$ & $135.46^{\mathrm{Aa}}$ & $44.1^{\mathrm{Bbc}}$ & $24.63^{\mathrm{Bc}}$ & $47.09^{\mathrm{Bb}}$ \\
Retention, \% of intakc & $4.93^{\mathrm{A}}$ & $3.84^{\mathrm{B}}$ & $1.22^{\mathrm{C}}$ & $0.64^{\mathrm{C}}$ & $1.04^{\mathrm{C}}$ \\
\hline
\end{tabular}

$\mathrm{a}, \mathrm{b}, \mathrm{c}-\mathrm{P}<0.05$

$\mathrm{A}, \mathrm{B}, \mathrm{C}-\mathrm{P}<0.01$ 
TABLE 4

Influcnce of manganese level, dietary fibre and $\mathrm{Na}$ phytate on $\mathrm{Fe}$ utilization

\begin{tabular}{lccccc}
\hline & \multicolumn{5}{c}{ Group } \\
\cline { 2 - 6 } Components & $\mathrm{C}$ & $\mathrm{CMn}$ & $\mathrm{CMnF}$ & $\mathrm{CMnFPh}$ & $\mathrm{L}$ \\
\hline Content in diet, mg/kg & 44.9 & 41.6 & 42.6 & 42.3 & 40.2 \\
Daily intake, mg & $0.51^{\mathrm{ab}}$ & $0.51^{\text {aj }}$ & $0.55^{\mathrm{a}}$ & $0.54^{\mathrm{a}}$ & $0.48^{\mathrm{b}}$ \\
Content in body, mg/rat & $7.40^{\mathrm{A}}$ & $7.38^{\mathrm{A}}$ & $7.05^{\mathrm{A}}$ & $6.76^{\mathrm{A}}$ & $5.36^{\mathrm{B}}$ \\
Retention, P $\mu \mathrm{g} / \mathrm{day}$ & $134.29^{\mathrm{Aa}}$ & $131.07^{\mathrm{Aab}}$ & $121.87^{\mathrm{Aab}}$ & $111.61^{\mathrm{Ab}}$ & $66.67^{\mathrm{BC}}$ \\
Retention, \% of intake & $26.47^{\mathrm{A}}$ & $26.55^{\mathrm{A}}$ & $22.12^{\mathrm{B}}$ & $20.81^{\mathrm{B}}$ & $13.78^{\mathrm{C}}$ \\
\hline
\end{tabular}

a, b, c - P $<0.05$

$\mathrm{A}, \mathrm{B}, \mathrm{C}-\mathrm{P}<0.01$

Daily retention and utilization of $\mathrm{Fe}$ in the control diet (C) and in the diet with the higher Mn content (CMn), were similar (Table 4). The Fe utilization coefficients in these groups were 26.5 and $26.6 \%$, respectively. Also in the experiment of Zdunczyk at al. (1996c) no differences were found in the retention of iron from diets with the white lupin seeds and with $\mathrm{Mn}$ content of about $0.45 \mathrm{~g} / \mathrm{kg}$. The addition of white lupin seeds hulls to the diet caused a significant $(\mathrm{P}<0.01)$ decrease in $\mathrm{Fe}$ utilization from the casein diet from 26.6 to $22.1 \%$. In the studies of other authors (Torre et al., 1991; Wing et al., 1995) lower iron availability was also found in diets with high fibre content. The lack of significant differences between groups CMnF (added hulls) and CMnFPh (added hulls and sodium phytate) may point to the minor effect of phytins on the utilization of iron from diets by growing rats. This is corroborated by the experiments of Lantzsch (1990) in which only a small, negative effect of sodium phytate was found on Fe absorption in young rats. However, a highly significant reduction of retention and utilization of iron, to levels half of those in control groups, were found in group $\mathrm{L}$, in which the rats were fed diet containing lupin seeds. This is in agreement with the results of $\mathrm{Kim}$ et al. (1995) who found that intestinal bioavailability of iron in rats fed diets containing protein from soyabean meal was distingtly lower than in those fed a casein-containing diet. In vegetable products most of the iron is in the form of phytates, part of which (monoferrous phytates) are easily available, and part (di- and tetraferrous phytates) is not easily utilized by monogastric animals (Brzozowska, 1991).

Magnesium intake in the particular groups was proportional to the content of this clement in the diets (Table 5). The magnesium utilization coefficient was the highest $(24.1 \%)$ in the control group. Increasing the Mn content in the casein diet from 0.06 to over $0.3 \mathrm{~g} / \mathrm{kg}$ did not adversely affect the retention of magnesium by rats, while the addition of lupin seed hulls decreased magnesium retention and utilization ( $\mathrm{P}<0.01$ ), despite increased uptake of this element. Torre et al. (1991) and De Schrijver and Conrad (1992) also reported the negative effect of dietary 
TABLE 5

Influence of manganese level, dietary fibre and $\mathrm{Na}$ phytate on $\mathrm{Mg}$ utilization

\begin{tabular}{lccccc}
\hline & \multicolumn{5}{c}{ Group } \\
\cline { 2 - 6 } Components & $\mathrm{C}$ & $\mathrm{CMn}$ & $\mathrm{CMnF}$ & $\mathrm{CMnFPh}$ & $\mathrm{L}$ \\
\hline Content in diet, $\mathrm{g} / \mathrm{kg}$ & 0.21 & 0.22 & 0.26 & 0.26 & 0.51 \\
Daily intakc, mg & $2.39^{\mathrm{C}}$ & $2.67^{\mathrm{C}}$ & $3.31^{\mathrm{B}}$ & $3.34^{\mathrm{B}}$ & $6.09^{\mathrm{A}}$ \\
Content in body, mg/rat & $44.0^{\mathrm{ABab}}$ & $45.92^{\mathrm{Aa}}$ & $40.71^{\mathrm{BCc}}$ & $41.78^{\mathrm{Bbc}}$ & $37.66^{\mathrm{Cd}}$ \\
Retention, $\mu \mathrm{g} /$ day & $576.3^{\mathrm{Aab}}$ & $607.4^{\mathrm{Aa}}$ & $418.1^{\mathrm{Alcc}}$ & $460.8^{\mathrm{A} B b c}$ & $350.2^{\mathrm{Bc}}$ \\
Retention, \% of intake & $24.11^{\mathrm{A}}$ & $23.96^{\mathrm{A}}$ & $12.79^{\mathrm{B}}$ & $14.62^{\mathrm{B}}$ & $5.79^{\mathrm{C}}$ \\
\hline
\end{tabular}

$a, b, c, d-P<0.05$

$A, B, C-P<0.01$

fibre on magnesium utilization. The addition of sodium phytate to the diet of group $\mathrm{CMnFPh}$ had not negative effect either on $\mathrm{Mg}$ retention or utilization. Different results were reported by Brink et al. (1991), who found that the addition of sodium phytate to a casein diet in amounts equal to those in the soyabean diet decreased $\mathrm{Mg}$ absorption to levels observed in the group of rats fed the soyabean diet. The lowest values of both daily and percentage retention of this element were found in group $\mathrm{L}$, despite the highest daily $\mathrm{Mg}$ intake in this group, twice that in other groups. Because the fibre and phytate levels in the group $\mathrm{L}$ diet were similar to those in the $\mathrm{CMnFPh}$ diet, it can be postulated that other components of white lupin seeds affected dietary mineral utilization. From the studies of Brink et al. (1991) it results that the replacement of casein with vegetable protein (soya) decreases intestinal magnesium uptake and increases urinary excretion of this element. In vegetable products, a considerable proportion of magnesium is found in the phytate complexes that are less efficiently utilized (Torre et al., 1991).

The additional amount of manganese in the diet of group CMn did not lower the retention and utilization of phosphorus in comparison with the control diet

TABLE 6

Infuence of manganesc level, dictary fibre and Na phytatc on $\mathrm{P}$ utilization

\begin{tabular}{lccccc}
\hline & \multicolumn{5}{c}{ Group } \\
\cline { 2 - 6 } Components & $\mathrm{C}$ & $\mathrm{CMn}$ & $\mathrm{CMnF}$ & $\mathrm{CMnFPh}$ & $\mathrm{L}$ \\
\hline Content in diet, g/kg & 6.5 & 6.4 & 6.3 & 6.8 & 6.7 \\
Daily intake, mg & $73.4^{\mathrm{Ab}}$ & $78.01^{\mathrm{ARab}}$ & $81.69^{\mathrm{ABa}}$ & $86.03^{\mathrm{Aa}}$ & $78.98^{\mathrm{AaAb}}$ \\
Content in body, g/rat & $1.00^{\mathrm{Aab}}$ & $1.08^{\mathrm{Aa}}$ & $0.98^{\mathrm{Abc}}$ & $0.98^{\mathrm{ABc}}$ & $0.89^{\mathrm{Bc}}$ \\
Retention, $\mu \mathrm{g} /$ day & $20.56^{\mathrm{ABb}}$ & $23.4^{\mathrm{Aa}}$ & $19.77^{\mathrm{ABb}}$ & $19.8^{\mathrm{Abb}}$ & $16.84^{\mathrm{Bc}}$ \\
Retention, \% of intake & $28.92^{\mathrm{Ab}}$ & $30.91^{\mathrm{Aa}}$ & $24.9^{\mathrm{Bc}}$ & $23.01^{\mathrm{BCC}}$ & $21.33^{\mathrm{Ce}}$ \\
\hline
\end{tabular}

$\mathrm{a}, \mathrm{b}, \mathrm{c}, \mathrm{d}, \mathrm{e}-\mathrm{P}<0.05$

$A, \mathrm{~B}, \mathrm{C}-\mathrm{P}<0.0 \mathrm{l}$ 
(Table 6). $\Lambda$ s the result of adding lupin hulls to the CMn diet, a significant $(\mathrm{P}<0.05)$ decrease in phosphorus retention from $23.4 \mathrm{mg} /$ day in group $\mathrm{CMn}$ to $19.8 \mathrm{mg} /$ day in group $\mathrm{CMnF}$ occurred, and the relative retention coefficient declined $(\mathrm{P}<0.01)$ from 30.9 to $24.9 \%$, respectively. De Schrijver and Conrad (1992) obtained different results, since they did not find significant changes in phosphorus retention due to increasing dietary fibre content in the diets of rats within the range of $6-57 \mathrm{~g} / \mathrm{kg}$. The lowest $P$ retention was found on the $L$ diet, in which the source of protein was white lupin seeds. In this diet, part of the phosphorus was from lupin seeds where it is bound to phytic acid, which decreases the bioavailability of minerals (Torre et al., 1991).

\section{CONCLUSIONS}

The experiments did not show a negative effect of an increased level of manganese (over five times the amount in a standard casein diet) on the utilization of casein diets and retention of $\mathrm{Mg}, \mathrm{Fe}$ and $\mathrm{P}$ in the body of rats. The addition of $10 \%$ lupin hulls to the casein diet caused a significant decrease in feed utilization and reduced the retention of the trace elements under study. The addition of sodium phytate $(2.25 \mathrm{~g} / \mathrm{kg})$ did not affect the true digestibility and protein efficiency ratio, and did not lower the retention of $\mathrm{Mg}$ and $\mathrm{Fe}$, but did decrease the utilization of $\mathrm{Mn}$ and $\mathrm{P}$ by rats. The bioavailability coefficients of $\mathrm{Mg}, \mathrm{Fe}$ and $\mathrm{P}$ of diets containing white lupin seeds were significantly lower than for the casein diet containing manganese, fibre and phytate in amounts close to the level of these components in diets containing white lupin seeds. This indicates that other constituents of lupin seeds limit the bioavailability of minerals.

\section{REFERENCES}

Batterham E.S., 1979. Lupinus albus cv. Ultra and Lupinus angustifolius cv. Unicrop as protein concentrates for growing pigs. Aust. J. Agric. Res. 30, 369-375

Brink E.J., Dekker P.R., Van Bcrenstcjn E.C.H., Bcynen A.C.,1991. Inhibitory effect of dietary soybean protein vs. casein on magnesium absorption in rats. J. Nutr.121, 1374-1381

Brzozowska A., 1991. Effect of phytates on iron, zinc and copper utilization in animals and human (in Polish). Bromat. Chem. Toksykol. 34, 167-170

Checke P.R., Kelly J.D., 1989. Metabolism, toxicity and nutritional implications of quinolizidine (lupin) alkaloids. In: J. Huisznan, T.F. B. van der Poel, I.E. Liener (Editors). Recent advances of research in antinutritional factors in legume seeds. Pudoc, Wageningen, pp. 189-201 
Davies N.T., Nightingale R.,1975. The effects of phytate on intestinal absorption and secretion of zinc, and whole-body retention of $\mathrm{Zn}$, copper, iron and manganese in rats. Brit.J. Nutr. 34, $243-258$

Eggum B.O.,1973. A study of certain factors influencing protein utilisation in rats and pigs. National Institute of Animal Scicnce, Beretning fra Forsøgslabortoriet, 406, Copenhagen

Eggum B.O., Beames R.M.. Wolstrup J., Bach Knudsen K.E., 1984. The effect of protein quality and fibre level in the diet and microbial activity in the digestive tract on protein utilization and energy digestibility in rats. Brit. J. Nutr. 51, 305-314

Eggum B.O., Tomes G., Beames R.M., Datta F.U.,1993. Protein and energy evaluation with rats of seed from 11 lupin cultivars. Anim. Feed Sci. Technol. 43, 109-119

Hung T.V., Itandson P.D., Amenta V.C., Kyle W.S.A., Yu R.S-T., 1987. Content and distribution of manganese in lupin seed grown in Victoria and in lupin flour, spray-dried powder and protein isolate prepared from the seeds. J. Sci. Food $\Lambda$ gric. 41,131-139

Hurley L.S., Keen C.L., 1987. Manganese. In: W. Mertz (Editor). Trace elements in human and animal nutrition. Academic Press, San Dicgo, CA, USA, 185-223

Kim M., I ee D-T., I ee Y-S., 1995. Iron absorption and intestinal solubility in rats are influenced by dietary proteins. Nutr. Res.15, 1705-1716

Lantzsch H.J., 1990. Untcrsuchungen über Ernährungsphysiologische Efekte des Phytats bei Monogastieren (Ratle, Schwein). Übers. Tierernähr. 18, 197-212

Lopez-Guisa J.M., Harned M.C., Dubielzig R., Rao S.C., Marlet J.A. 1988. Oat hulls as potential dietary source in rats. J. Nutr. 118, 953-962

Miller E.R., 1991. Iron, copper, zinc, manganesc and iodinc in swine nutrition. In: Swinc Nutrition. Miller E.R., Ullrey D.E.. Lewis A.J. (Editors). Butterworth-Heinemann, USA, 15, 267-284

Przybilla P., Pallauf J., 1991. Studies on manganese deficiency in the growing rat. Agribiol. Res. 44, 63-69

Rakowska M., Szkiłłądziowa W., Kunachowic7. II., 1978. Biological Value of Food Protein (in Polish). WNI, Warszawa.

De Schrijver R., Conrad S., 1992. Availability of calcium, magnesium, phosphorus, iron and zinc in rats fed oat bran containing diets. J. Agric. Food Chem. 40, 1166-1171

Smulikowska S., Chibowska M., 1993. The effect of variety, supplementation with iryptophan, dehulling and autoclaving on utilization of field bean (Vicia faba L.) seeds by broiler chickens. $\mathbf{J}$. Anim Feed Sci. 2, 181-189

Torre M., Rodriguez A.R., Saura-Calixto F., 1991. Effects of dictary fibre and phytic on mincral availability. Cril. Rev. Food Sci. Nutr. I. 1-22

Weigland E., Kirchgessner K., Helbig U., 1986. True absorption and endogenous fecal excretion of manganese in relation to its dietary supply in growing rats. Biol. Trace Element Res.10, 265-279

Wing K., Wing A., Tiđchag P., Hallznans G., Sunzel B., Sjöström R., 1995. The availability of iron, zinc and cadmium to rats from composite diets with different cereal grains. Nutr. Res. $15,1525-1534$

Zduńczyk Z., Juśkiewicz J., Flis M., 1996a. Effect of dehulling white lupin (Lupinus albus) on protein utilization by rats. J. Anim. Feed Sci. 5, 281-288

Zduńczyk Z., Juśkicwicz J., Flis M., Frcjnagcl S., 1996b. The chemical composition and nutritive value of low-alcaloid varieties of white lupin 2. Oligosaccharides. phytates. fatty acids and biological value of protein. J. Anim. Feed Sci. 5, 73-82

Zduńczyk Z., Juśkiewicz J., Flis M., Markiewicz K., 1996c. The manganese content in white lupin sceds: Effect on diet intake, rat growth and microclement retention (in Polish). Zcsz. probl. Post. Nauk rol. 434, 729-734 
Zduńczyk Z., Juśkiewicz J., Frejnagel S., Flis M., Godycka I., 1994. Chemical composition of the cotyledons and seed coat and nutritional value of whole and dehulled seeds of yellow lupin. J. Anim. Feed Sci. 3, 141-148

Zhao X., Jorgensen H., Eggum B., 1995. The influence of dictary fibre on body composition, visceral organ weight, digestibility and energy balance in rats housed in different thermal environments. Brit. J. Nutr. 73, 687-699

\section{STRESZCZENIE}

Wykorzystanic bialka i składników mineralnych diet zawierających nasiona lubinu bialego lub kazeinę z dodatkiem okrywy nasiennej lubinu, manganu i fitynianu sodu

W doświadezeniach na ščurach badano, čy duża, charakterystyczna dla nasion fubinu bialego, zawartość manganu, wlókna i fitynianów wpływa na wykorzystanie białka i składników mineralnych. Wysoki poziom manganu $w$ diccic kareinowej, zblizony do zawartości $\mathrm{Mn} w$ diecic zawierającej lubin (ok. $0,3 \mathrm{~g} / \mathrm{kg}$ ), nie miał ujennego wpływu na wykorzystanie bialka diety oraz retencję $\mathrm{Mn}, \mathrm{Mg}, \mathrm{Fc}$ i $\mathrm{P}$ w tuszy szczurów. Dodatck okrywy nasiennej tubinu w ilosici $10 \%$ diety spowodował istotne pogorszenic strawności $(89,5 \mathrm{vs} 92,8 \%$ ) i wydajności wrrostowej białka (2,8 vs 3,03 ) oraz zmniejszenic retencji składników mineralnych w porównaniu z dietą kontrolną. Retencja manganu zmalała 73,84 do $1,22 \%$ ilości spożytej, fosforu z 30,9 do $24,9 \%$, magnezu z. 24 do $12,8 \%$ oraz żelaza z 26,6 do $22.1 \%$. Dodatek fitynianu sodu do diety kazeinowej zawicrającej okrywę nasienną z.mniejszył jedynie biodostçpność nanganu (z 1,22 do $0,64 \%$ ) i fosforu (z 24.9 do $23.0 \%$ ). Wykorzystanic P. Mg i Fe było najmniejsze u zwicrą̧ żywionych dictą zawierającą nasiona łubinu białego. 